\title{
PENGGUNAAN VIDEO ANAK "PERTUALANGAN ALICE DI NEGERI AJAIB" UNTUK MENINGKATKAN KEMAMPUAN SISWA MENULIS CERITA FANTASI DI KELAS VII H SMP NEGERI 2 SAWAN
}

\author{
Kadek Rudy Saputra ${ }^{1}$, I Made Sutama², Gede Gunatama ${ }^{3}$ \\ Jurusan Pendidikan Bahasa dan Sastra Indonesia, Fakultas Bahasa dan Seni \\ Universitas Pendidikan Ganesha \\ Singaraja, Indonesia \\ e-mail: kadekrudys48@gmail.com, imadesutamaubd@gmail.com, \\ gedegunatama22@gmail.com
}

\begin{abstract}
ABSTRAK
Penelitian tindakan kelas yang dilakukan di SMP Negeri 2 Sawan ini bertujuan (1) mendeskripsikan langkah-langkah meningkatkan keterampilan menulis cerita fantasi dengan penggunaan video anak "pertualangan Alice di negeri ajaib" pada siswa kelas VII H SMP Negeri 2 Sawan, (2) mendeskripsikan peningkatan kemampuan siswa menulis cerita fantasi melalui video anak "pertualangan Alice di negeri ajaib" pada siswa kelas VII H SMP Negeri 2 Sawan, dan (3) mendeskripsikan respons siswa terhadap penggunaan video anak "pertualangan Alice di negeri ajaib" dalam meningkatkan keterampilan menulis cerita fantasi di kelas VII H SMP Negeri 2 Sawan. Penelitian ini dilaksanakan dengan dua siklus dan menggunakan lima tahap penelitian tindakan kelas, yakni (1) refleksi awal, (2) perencanaan tindakan, (3) pelaksanaan, (4) observasi dan evaluasi, dan (5) refleksi. Data dikumpulkan dengan metode observasi, tes, angket/ kuisioner, serta wawancara dan dianalisis secara deskriptif kuantitatif dan kualitatif. Hasil penelitian menunjukkan nilai rata-rata siklus I adalah 77,58 atau mengalami peningkatan 8,75 dari nilai sebelumnya (prasiklus) 68,83 . Nilai ratarata siklus II adalah 81,58 atau meningkat 4 poin dari siklus I dan meningkat 12,75 dari nilai rata-rata prasiklus. Perolehan rata-rata respons siswa pada siklus I sebesar 41,51 dalam kategori setuju dan pada siklus II mengalami peningkatan sebesar 46,77 dalam kategori sangat setuju.
\end{abstract}

Kata Kunci: menulis, video anak, cerita fantasi.

\begin{abstract}
This classroom action study was done in SMP N 2 Sawan and aimed for: 1) describing the steps to improve the skill to write a fantasy story by using movie for children entitled "Alice in Wonderland" to $7^{\text {th }}$ grade students in SMP N 2 Sawan. 2) describing the rate of improvement of the skill to write a fantasy story by using movie for children entitled "Alice in Wonderland" to $7^{\text {th }}$ grade students in SMP N 2 Sawan and 3) describing student's response toward movie for children entitled "Alice in Wonderland" to improve writing skill for $7^{\text {th }}$ grade students in SMP N 2 Sawan. This study was done by using 2 cycles and 5 steps of classroom action research such as 1) early reflection 2) planning 3) applying 4) observation an evaluation and 5) reflection. The data was collected by using observation method, test, questionnaire, and interview. The data was analyzed descriptively qualitative and quantitatively. The result showed that the $1^{\text {st }}$ cycle's average was 77.58 or increase 8.75 from 68.83 in pre-cycle. The $2^{\text {nd }}$ cycle's average was 81.58 or increase 4 point from $1^{\text {st }}$ cycle an increase 12.75 from pre-cycle's average. The response data from the students in $1^{\text {st }}$ cycle was 41.51 in affirmative position and $2^{\text {nd }}$ cycle was 46.77 in very affirmative position.
\end{abstract}

Keywords: writing, movie for children, fantasy story. 


\section{PENDAHULUAN}

Tarigan (1994) mengemukakan menulis merupakan suatu keterampilan berbahasa yang digunakan untuk berkomunikasi secara tidak langsung, tidak secara tatap muka dengan orang lain. Berdasarkan urutannya sebagai salah satu aspek keterampilan berbahasa, keterampilan menulislah yang dianggap paling sulit di antara menyimak, membaca, dan berbicara. Hal tersebut dikarenakan, di dalam proses menulis, penulis dituntut untuk menuangkan ideide, pikiran, dan perasaan secara logis dan sistematis.

Sehubungan dengan hal itu, Kartono (2009) menambahkan bahwa menulis merupakan suatu penuangan pikiran dan menyampaikan kepada khalayak. Ini berarti, melalui kegiatan menulis seseorang bisa mengembangkan gagasan. Kegiatan menulis dapat membantu seseorang untuk mengembangkan gagasan yang ada dalam pikirannya.

Keterampilan menulis merupakan salah satu keterampilan berbahasa. Keterampilan ini berkaitan dengan keterampilan lain, yakni membaca. Keterampilan menulis adalah kemampuan mengekspresikan pikiran melalui lambang-lambang tulisan. Keterampilan menulis ini termasuk ke dalam jenis keterampilan aktif karena penulis aktif mengelola pesan (informasi) yang disampaikan kepada pembaca. Terkadang sulit membedakan menulis dan mengarang. Dalam pelajaran bahasa Indonesia, ada perbedaan yang mendasar antara menulis dengan mengarang.

Menulis merupakan keterampilan yang mensyaratkan penguasaan bahasa yang baik. Dalam belajar bahasa, menulis merupakan kemahiran tingkat lanjut. Semi (1990) berpendapat bahwa pengajaran menulis merupakan dasar untuk keterampilan menulis. Menulis merupakan penguasaan kaidah tata tulis, yakni ejaan dan kaidah tata bahasa, morfologi, dan sintaksis. Di samping itu, penguasaan kosakata yang banyak juga diperlukan.
Menulis cerita fantasi berarti berbagi cerita kepada orang lain melalui tulisan. Menulis cerita fantasi sangatlah banyak manfaatnya, terutama bagi siswa. Pertama, dapat melatih siswa untuk berani mengekspresikan diri melalui kata-kata tanpa harus ada lawan bicara dalam menyampaikan sesuatu. Kadang-kadang, siswa tidak mudah menyampaikan sesuatu secara langsung dengan orang lain, karena mereka membutuhkan mental dan keberanian sikap dalam berbicara. Kedua, menulis cerita fantasi dapat menuntut siswa memasuki dunia seni, terutama seni sastra. Ketiga, menulis adalah media belajar dalam menyampaikan sebuah ide atau gagasan. Keempat, dengan menulis cerita fantasi siswa dapat mengembangkan atau meningkatkan daya imajinasinya. Dengan menulis, akan mendorong dan menuntut siswa dalam menyerap, menggali, dan mengumpulkan informasi yang berupa teoretis maupun bersifat fakta.

Menulis cerita fantasi juga dapat membuat siswa mudah dalam menemukan ide-ide baru. Dengan menulis cerita fantasi, siswa akan berpikir dan terus berusaha mengembangkan pemahaman dan kemampuan siswa. Motivasi inilah yang akan mendobrak siswa menemukan ide-ide baru, karena di saat siswa menggeluti dunia tulis-menulis, siswa terus tertantang membuat gebrakan baru untuk mengeluarkan ide-ide dan gagasan mereka.

Berdasarkan pengalaman penulis selama melakukan PPL-Real di SMP Negeri 2 Sawan, penulis menemukan suatu permasalahan yang dialami oleh siswa saat mengikuti pembelajaran Bahasa Indonesia dengan materi menulis cerita fantasi. Masalah yang sering dihadapi siswa dalam menulis cerita fantasi yakni siswa kesulitan dalam menuangkan ide cerita, lemahnya daya imajinasi siswa terlihat saat siswa membuat cerita fantasi mengikuti cerita yang ada di buku paket bahasa Indonesia, dan kurang memahami struktur cerita fantasi. Di dalam teks cerita fantasi terdapat struktur cerita fantasi, yaitu: (1) 
orientasi, (2) komplikasi, dan (3) resolusi. Siswa masih kebingungan apa saja yang terdapat pada orientasi, komplikasi, dan resolusi. Bahkan tidak tahu letak tempat orientasi, komplikasi, dan resolusi.

Berdasarkan hasil observasi awal, masalah di atas ditemukan di kelas VII H SMP Negeri 2 Sawan. Penulis memeroleh informasi bahwa keterampilan menulis cerita fantasi siswa masih rendah. Hal ini terbukti dari skor rata-rata menulis siswa sebesar 68,83, sedangkan ketuntasan hasil belajar yang harus dicapai rata-rata minimal 75. Kurangnya keberhasilan siswa dalam belajar bahasa Indonesia materi menulis disebabkan oleh beberapa faktor, yaitu: (1) siswa kurang terpancing dalam mengeluarkan ide-ide dalam menulis, (2) siswa kurang aktif saat pembelajaran, (3) siswa masih belum paham mengenai materi cerita fantasi, dan (4) siswa cenderung bosan karena kegiatan pembelajaran kurang menarik dan proses pembelajaran tersebut dipandang monoton.

Alasan mendasar penelitian ini dilakukan di kelas VII H SMP Negeri 2 Sawan, karena sesuai dengan Kurikulum 2013, dalam silabus tersebut, telah tercantum materi pembelajaran menulis, tertulis dalam bentuk menyusun teks deskriptif, prosedur, teks hasil observasi, dan narasi (cerita fantasi) sesuai karakteristik teks yang akan dibuat baik secara lisan maupun tulisan. Dalam hal ini, siswa dituntut untuk mampu menulis karangan berupa narasi atau cerita fantasi.

Untuk membangkitkan kreativitas siswa pada saat proses belajar mengajar, guru hendaknya mampu memanfaatkan media pembelajaran dengan baik. Dalam pembelajaran, media pembelajaran juga memegang peranan yang cukup penting. Media pembelajaran membantu siswa dalam belajar. Nugraha (2008) menyatakan bahwa media adalah segala sesuatu yang dapat digunakan untuk menyalurkan pesan dari pengirim ke penerima sehingga dapat merangsang pikiran, perasaan, dan minat serta siswa sedemikian rupa sehingga belajarmengajar terjadi.
Media pendidikan sebagai salah satu sumber belajar ikut membantu guru dalam memperkaya wawasan anak didik. Aneka macam bentuk dan jenis media pendidikan yang digunakan oleh guru menjadi sumber ilmu pengetahuan bagi peserta didik. Dalam menerangkan suatu benda, guru dapat membawa bendanya secara langsung ke hadapan anak didik di kelas. Dengan menghadirkan bendanya seiring dengan penjelasan mengenai benda itu, maka benda itu dijadikan sebagai sumber belajar.

Media sebagai sumber belajar diakui sebagai alat bantu auditif, visual, dan audiovisual. Penggunaan ketiga jenis sumber belajar ini tidak sembarangan, tetapi harus disesuaikan dengan perumusan tujuan instruksional, dan tentu saja dengan kompetensi guru itu sendiri dan sebagainya. Media audio-visual merupakan sarana (media) yang mampu menampilkan gambar dan suara secara bersamaan. Melalui media ini seorang tidak hanya melihat atau mengamati sesuatu, melainkan mampu mendengar segala sesuatu yang divisualisasikan (Wiryawan dkk., 1988). Sejalan dengan itu Effendy (2006) menyatakan, media audiovisual adalah sebagai sarana dokumentasi dan media komunikasi dalam pembelajaran. Sebagai media dokumentasi tujuan utamanya, yaitu mendapatkan fakta suatu peristiwa, sebagai media komunikasi digunakan untuk sarana dalam memberikan pengetahuan bagi penikmatnya.

Djamarah dan Aswan Zain (1995) menyatakan bahwa media audio-visual adalah media yang mempunyai unsur suara dan unsur gambar. Media ini dapat dibagi menjadi beberapa jenis, seperti (a) audio-visual diam, yaitu media yang menampilkan suara dan gambar diam misalnya bingkai suara (sound slides), film rangkai suara, cetak suara, dan (b) audiovisual gerak yakni media yang menampilkan unsur suara dan gambar yang bergerak seperti film suara dan "video cassete". Rohani (1997) menyatakan, media audio visual merupakan instruksional modern yang sesuai dengan perkembangan zaman 
(kemajuan ilmu pengetahuan dan teknologi) meliputi media yang dapat dilihat dan didengar.

Salah satu media audio visual yang tepat digunakan sebagai media pembelajaran menulis cerita fantasi adalah video anak "Petualangan Alice di Negeri Ajaib". Video anak "Petualangan Alice di Negeri Ajaib" selain ditayangkan di stasiun televisi, video anak "Petualangan Alice di Negeri Ajaib" juga telah diunggahkan di internet (you tube) sehingga guru yang membutuhkan video ini dapat dengan mudah mengunduhnya.

Video "Pertualangan Alice di Negeri Ajaib" akan menumbuhkan daya imajinasi yang tinggi kepada setiap anak-anak yang menonton tayangan tersebut. Kelebihan video "Pertualangan Alice di Negeri Ajaib" dibandingkan dengan video-video lainnya sebagai media pembelajaran bahwa video ini lebih condong ke pembelajaran fiksi. Dengan adanya ciri-ciri cerita fantasi yang terdapat di dalam video, akan mempermudah siswa dalam menulis sesuatu berdasarkan video yang ditonton. Misalnya, dalam video anak "Pertualangan Alice di Negeri Ajaib" berlatarkan di negeri ajaib. Melihat adegan-adegan anak perempuan yang bernama Alice sedang bermain-main di negeri ajaib akan menginspirasi siswa dan membayangkan diri mereka sedang bermain. Jadi, fungsi media video anak "Pertualangan Alice di Negeri Ajaib" dapat menginspirasi siswa dalam sebuah cerita berdasarkan apa yang dilihat, didengarkan, dan dipikirkan.

Berdasarkan masalah tersebut, media yang peneliti akan gunakan untuk meningkatkan keterampilan menulis cerita fantasi, yaitu penggunaan video anak "Pertualangan Alice di negeri ajaib". Model "Pertualangan Alice di Negeri Ajaib" cocok digunakan sebagai media pembelajaran karena di dalam model tersebut diceritakan tentang kegiatan si Alice. Video anak "Pertualangan Alice di Negeri Ajaib" yang menggunakan latar negeri ajaib akan lebih memudahkan siswa dalam menciptakan ide-ide yang dapat dirangkai dalam bentuk cerita. Selain itu, alur cerita berdasarkan tema video tersebut akan menginspirasi siswa dalam menulis.

Peneliti menyadari bahwa sudah pernah ada penelitian terkait menulis dengan penggunaan video. Yang pertama adalah penelitian yang berjudul "Peningkatan Kemampuan Menulis Cerpen Menggunakan Media Video Klip Siswa Kelas VII 1 SMP Negeri 1 Tampaksiring" yang ditulis oleh I Made Sujana tahun 2012. Penelitian ini memiliki persamaan dengan penelitian yang dilakukan oleh penulis dalam hal menulis menggunakan media video dan subjek yang sama, yaitu tingkat SMP. Hasil penelitian ini adalah peningkatan belajar menulis cerpen melalui media video klip.

Penelitian sejenis kedua, berjudul "Penggunaan Pendekatan Saintifik Bermedia Video Anak "Si Bolang" untuk Meningkatkan Kemampuan Menulis Cerpen Pada Siswa Kelas VII 15 SMP Negeri 2 Singaraja" yang ditulis oleh $\mathrm{Ni}$ Putu Ayu Nila Purmita Sari tahun 2015. Penelitian ini membahas tentang menulis menggunakan video dengan pendekatan saintifik. Jadi, persamaannya dengan penelitian yang dilakukan peneliti yaitu sama-sama membahas tentang menulis menggunakan media video. Perbedaannya adalah penelitian sejenis yang kedua ini memilih cerpen (cerita pendek) sebagai subjek, sedangkan penelitian yang akan peneliti lakukan yaitu memilih cerita fantasi sebagai subjek. Hasil penelitian ini adalah peningkatan menulis cerpen melalui media video "Si Bolang".

Penelitian sejenis ketiga, berjudul "Penggunaan Media Audio Visual dalam Pembelajaran Menulis Teks Pidato di Kelas X IPA 8 SMA Negeri 1 Kuta Utara" yang ditulis oleh Made Rospita Pradnya Dewi tahun 2017. Penelitian ini membahas tentang menulis teks pidato menggunakan media audio visual. Jadi, persamaannya dengan penelitian yang dilakukan peneliti yaitu sama-sama membahas tentang menulis menggunakan media video. Perbedaannya adalah penelitian sejenis yang ketiga ini memilih teks pidato sebagai subjek, sedangkan penelitian yang akan peneliti lakukan yaitu 
memilih cerita fantasi sebagai subjek. Hasil penelitian ini adalah peningkatan menulis teks pidato melalui media audio visual.

Berdasarkan latar belakang di atas, peneliti melakukan sebuah penelitian dengan mengangkat penelitian yang berjudul "Penggunaan Video Anak "Pertualangan Alice di Negeri Ajaib" untuk Meningkatkan Kemampuan Siswa Menulis Cerita Fantasi di kelas VII H SMP Negeri 2 Sawan".

Berdasarkan pemaparan masalah di atas, Penelitian ini membahas tentang, (1) langkah-langkah meningkatkan kemampuan menulis cerita fantasi dengan penggunaan video anak "pertualangan Alice di negeri ajaib" pada siswa kelas VII H SMP Negeri 2 Sawan, (2) peningkatan kemampuan siswa menulis cerita fantasi melalui video anak "pertualangan Alice di negeri ajaib" pada siswa kelas VII H SMP Negeri 2 Sawan, dan (3) respons siswa terhadap penggunaan video anak "pertualangan Alice di negeri ajaib" dalam meningkatkan keterampilan menulis cerita fantasi di kelas VII H SMP Negeri 2 Sawan.

Sejalan dengan rumusan masalah yang telah diuraikan di atas, tujuan penelitian ini adalah untuk mendeskripsikan langkah-langkah meningkatkan kemampuan menulis cerita fantasi dengan penggunaan video anak "pertualangan Alice di negeri ajaib" pada siswa kelas VII H SMP Negeri 2 Sawan, mendeskripsikan peningkatan kemampuan siswa menulis cerita fantasi melalui video anak "pertualangan Alice di negeri ajaib" pada siswa kelas VII H SMP Negeri 2 Sawan, dan untuk mendeskripsikan respons siswa terhadap penggunaan video anak "pertualangan Alice di negeri ajaib" dalam meningkatkan keterampilan menulis cerita fantasi di kelas VII H SMP Negeri 2 Sawan.

Hasil dari penelitian ini diharapkan memberikan manfaat bagi siswa, guru, sekolah, dan peneliti lainnya.

\section{METODE PENELITIAN}

Penelitian ini menggunakan rancangan penelitian tindakan kelas.
Penelitian tindakan kelas ini dilaksanakan di SMP Negeri 2 Sawan. Subjek dalam penelitian ini adalah guru mata pelajaran bahasa Indonesia di kelas VII $\mathrm{H}$. Yang bernama I Putu Sudirga, S.Pd., dan siswa kelas VII H SMP Negeri 2 Sawan. Siswa kelas VII $\mathrm{H}$ dipilih sebagai subjek penelitian karena kemampuan menulis siswa masih kurang, karena dapat dilihat skor yang diperoleh siswa masih di bawah $\mathrm{KKM}$, padahal kriteria ketuntasan minimal (KKM) adalah 75.

Objek penelitian merupakan hal yang dikaji dalam penelitian tersebut. Objek dalam penelitian ini adalah penggunaan video anak "Pertualangan Alice di Negeri Ajaib" untuk meningkatkan kemampuan menulis siswa kelas VII $\mathrm{H}$ dan respons siswa terhadap pembelajaran.

Pelaksanaan penelitian tindakan kelas (PTK) dilakukan secara bertahap dan multisiklus. Hal ini dilakukan untuk mendapatkan hasil terbaik memeroleh data yang valid. Setiap siklus terdiri atas refleksi awal, dilanjutkan dengan rencana tindakan, pelaksanaan tindakan, observasi/ evaluasi, dan refleksi. Prosedur ini dimulai dari analisis masalah. Setelah menemukan kemudian dilakukan refleksi awal. Refleksi awal dilakukan untuk mengidentifikasi masalah yang dihadapi guru maupun siswa dalam pembelajaran. Sebelum tindakan dilakukan, membuat suatu perencanaan pembelajaran sangat diperlukan. Perencanaan tersebut akan menjadi pedoman dalam melaksanakan tindakan. Setelah membuat perencanaan dilanjutkan dengan pelaksanaan tindakan. Pelaksanaan tindakan harus disesuaikan dengan perencanaan yang telah dibuat. Setelah pelaksanaan tindakan, dilakukan observasi untuk mengetahui pemantauan terhadap berlangsungnya siklus. Refleksi digunakan untuk tindakan selanjutnya, yang bertujuan memformulasikan kekuatan-kekuatan, kelemahankelemahan, dan hambatan-hambatan yang ditemukan dan dianggap mengganjal dalam upaya pencapaian keberhasilan optimal. Prosedur ini akan dilakukan berulang-ulang sampai data yang di dapat menunjukkan hasil terbaik atau telah 
memenuhi kriteria keberhasilan yang telah ditentukan.

Metode pengumpulan data merupakan langkah paling utama dalam penelitian karena tujuan utama dari penelitian adalah memeroleh data yang memenuhi standar data yang ditetapkan. Dalam pengumpulan data penelitian, peneliti menggunakan beberapa metode pengumpulan data.

Pertama, untuk mengetahui langkahlangkah meningkatkan kemampuan menulis cerita fantasi siswa, peneliti menggunakan metode observasi sebagai penilaian proses. Kedua, untuk mengetahui peningkatan kemampuan menulis cerita fantasi siswa, peneliti menggunakan metode tes sebagai penilaian hasil. Ketiga, untuk mengetahui respons siswa, peneliti menggunakan metode angket/ kuesioner dan wawancara.

Penelitian ini menggunakan instrumen pokok, yaitu instrumen tes dan instrumen nontes. Instrumen yang berupa tes digunakan untuk mengukur tingkat kemampuan menulis siswa. Instrumen tes berupa soal esai yang harus dikerjakan oleh siswa setelah mereka menonton video anak dan mengamati contoh teks cerita fantasi. Sedangkan instrumen nontes berupa lembar observasi, kuesioner dan wawancara.

Dalam penelitian tindakan kelas ini, peneliti menggunakan teknik analisis data deskriptif kuantitatif dan deskriptif kualitatif. Berdasarkan ketiga jenis data yang diperoleh, langkah-langkah meningkatkan kemampuan menulis dianalisis dengan teknik analisis data deskriptif kualitatif, hasil kemampuan menulis siswa dianalisis dengan deskriptif kuantitatif dan kualitatif, dan respons siswa dianalisis dengan deskriptif kuantitatif dan kualitatif.

Analisis data hasil belajar dilakukan untuk kedua siklus, yaitu siklus I dan siklus II dengan tujuan mengukur hasil kemampuan menulis cerita fantasi dengan penggunaan video anak "Pertualangan Alice di Negeri Ajaib". Hasil tes pada siklus I dianalisis, dilanjutkan dengan mencari kesulitan-kesulitan yang dialami siswa atau kelemahan siswa dalam hal menulis. Pada siklus II diharapkan siswa mendapatkan hasil yang baik.

Kriteria keberhasilan penelitian masing-masing aspek adalah kemampuan menulis siswa dikatakan berhasil apabila $75 \%$ dari keseluruhan memeroleh nilai 75 ke atas atau melebihi $\mathrm{KKM}, 75 \%$ siswa memberikan respons setuju terhadap penggunaan video anak "Pertualangan Alice di Negeri Ajaib"dalam pembelajaran menulis.

\section{HASIL DAN PEMBAHASAN Hasil Penelitian}

Setelah dilakukan penelitian mengenai kemampuan menulis cerita fantasi dengan penggunaan video anak "Pertualangan Alice di Negeri Ajaib" di kelas VII H SMP Negeri 2 Sawan, dapat diketahui hasil penelitian sebagai berikut.

Berdasarkan hasil observasi yang dilakukan, dapat dikatakan bahwa langkah-langkah pelaksanaan pembelajaran yang dilakukan guru sudah tergolong baik/bagus. Hal ini dapat dilihat dari penilaian yang diberikan peneliti atau observer saat mengamati guru mengajar.

Pada tindakan siklus I yang dilaksanakan dalam dua kali pertemuan, dari 14 aspek yang harus dilakukan guru, hanya 3 (tiga) aspek yang tidak terlaksana berdasarkan rencana yang telah disusun sebelumnya. Ketiga aspek tersebut, yaitu (1) guru tidak menyampaikan KD dan tujuan pembelajaran dan langsung masuk pada kegiatan inti menjelaskan materi. (2) guru tidak memfasilitasi atau membimbing siswa dalam membuat rangkuman hasil pembelajaran, tetapi langsung memberikan tugas rumah/PR. (3) guru tidak menyampaikan rencana pembelajaran pada pertemuan berikutnya, dan langsung mengakhiri dan menutup pembelajaran karena keterbatasan waktu.

Hasil tes pada siklus I dalam kemampuan menulis siswa kelas VII H SMP Negeri 2 Sawan, dapat dilihat dalam tabel sebagai berikut.

Tabel 1.1 Hasil Tes Menulis Cerita Fantasi Siswa Pada Siklus I

\begin{tabular}{|l|l|l|l|l|}
\hline No & Kat. & S. & F. & $\%$ \\
\hline
\end{tabular}




\begin{tabular}{|c|c|c|c|c|}
\hline 1. & SB & $90-100$ & 0 & 0 \\
\hline 2. & B & $75-89$ & 24 & 77 \\
\hline 3. & C & $60-74$ & 7 & 23 \\
\hline 4. & K & $40-59$ & 0 & 0 \\
\hline 5. & SK & $0-39$ & 0 & 0 \\
\hline & Jml. & & 31 & 100 \\
\hline
\end{tabular}

Berdasarkan tabel hasil keseluruhan pada siklus I, diperoleh rata-rata 77,58 yang secara klasikal berkategori baik.

Pada tabel di atas diketahui bahwa tidak ada siswa yang mencapai kategori sangat baik. Kategori baik dicapai oleh 24 siswa atau sebesar 77\%, kategori cukup dicapai oleh 7 siswa atau sebesar 23\% dan tidak ada yang mendapat kategori kurang maupun sangat kurang. Nilai ratarata menulis siklus I adalah 77,58 yang termasuk dalam kategori baik. Dengan nilai rata-rata tersebut maka ada peningkatan sebesar 8,75 dari nilai pratindakan 68,83 menjadi 77,58 pada siklus I. Namun, jika dilihat dari nilai yang ditargetkan pada siklus I yaitu 75 maka masih ada 7 siswa yang masih berada di bawah nilai rata-rata. Oleh karena itu, peneliti melanjutkan pada siklus II dengan harapan siswa mampu mencapai nilai 75 .

Berdasarkan hasil respons siswa pada siklus I, dapat dirinci bahwa dari 31 orang siswa yang mengisi kuesioner angket, ada 10 orang (32\%) yang memberikan respons sangat positif. 21 orang (67\%) memberikan respons setuju terhadap penggunaan video anak "Petualangan Alice di Negeri Ajaib" untuk meningkatkan kemampuan menulis siswa. Dan yang lainnya tidak ada yang memberikan respons cukup, kurang setuju, dan tidak setuju.

Berdasarkan hasil observasi yang peneliti lakukan selama tindakan pada siklus I, pelaksanaan penelitian sudah berlangsung dengan baik. Pembelajaran menulis cerita fantasi dengan penggunaan video anak "Pertualangan Alice di Negeri Ajaib" sudah berjalan dengan lancar dan sesuai dengan rencana, walaupun sebagian siswa masih belum terbiasa dengan kehadiran media video yang digunakan peneliti.

Hambatan-hambatan yang ditemukan ketika observasi adalah berikut ini (a)
Interaksi guru dan siswa kurang efektif. Saat guru menjelaskan materi, banyak siswa yang kurang fokus. (b) Kurangnya konsentrasi siswa. (c) Siswa masih sedikit sulit untuk menemukan ide menulis cerita fantasi. (d) Siswa masih belum mampu menulis cerita fantasi dengan benar. Ratarata hasil tes menulis siswa dengan penggunaan video anak "Pertualangan Alice di Negeri Ajaib" pada siklus I sudah mencapai kriteria ketuntasan minimal, yakni 77,58. Tetapi masih ada beberapa siswa yang nilainya masih di bawah KKM, sehingga tindakan akan dilanjutkan ke siklus II.

Berikut hasil keseluruhan pada siklus II. Hasil observasi pada pelaksanaan pembelajaran pada siklus II, bahwa langkah-langkah kegiatan pembelajaran yang dilakukan oleh guru tergolong sangat baik. Hal itu dapat diamati dari penilaian yang diberikan oleh observer/peneliti saat mengamati guru. Pada siklus II yang dilaksanakan dua kali pertemuan, terdapat 14 aspek yang dilakukan oleh guru. Ternyata, semua aspek telah dilaksanakan dalam kegiatan pembelajaran dengan baik. Guru sudah melaksanakan kegiatan pembelajaran ini sesuai prosedur yang sudah direncanakan pada kegiatan refleksi siklus I. Pelaksanaan pembelajaran pada siklus II sudah dapat dikatakan lebih baik dari pelaksanaan pembelajaran siklus I.

Berdasarkan hasil tes pada siklus II kemampuan menulis siswa kelas VII H SMP Negeri 2 Sawan, dapat dilihat dalam tabel berikut ini.

Tabel 1.2 Hasil Tes Menulis Cerita Fantasi Siswa Pada Siklus II

\begin{tabular}{|c|c|c|c|c|}
\hline No & Kat. & S. & F. & $\%$ \\
\hline 1. & SB & $90-100$ & 1 & 3,22 \\
\hline 2. & B & $75-89$ & 30 & 96,77 \\
\hline 3. & C & $60-74$ & 0 & 0 \\
\hline 4. & K & $40-59$ & 0 & 0 \\
\hline 5. & SK & $0-39$ & 0 & 0 \\
\hline & Jml. & & 31 & 100 \\
\hline
\end{tabular}

Berdasarkan tabel hasil keseluruhan pada siklus II, diperoleh rata-rata 81,58 yang secara klasikal berkategori baik. 
Pada tabel di atas diketahui bahwa kategori sangat baik dicapai oleh 1 siswa atau sebesar 3,22\% dan kategori baik dicapai oleh 30 siswa atau sebesar $96,77 \%$. Nilai rata-rata menulis siklus II adalah 81,58 yang termasuk dalam kategori baik. Dengan nilai rata-rata tersebut maka ada peningkatan sebesar 4 dari siklus I.

Berdasarkan hasil respons siswa pada siklus II, dapat dirinci bahwa dari 31 orang siswa yang mengisi kuesioner angket, ada 4 orang (13\%) yang memberikan respons setuju dan 27 orang (87\%) memberikan respons sangat positif terhadap penggunaan video anak "Pertualangan Alice di Negeri Ajaib" untuk meningkatkan kemampuan menulis siswa. Dan yang lainnya tidak ada yang memberikan respons cukup, kurang setuju, dan tidak setuju. Rata-rata respons siswa terhadap penggunaan video anak "Pertualangan Alice di Negeri Ajaib" untuk meningkatkan kemampuan menulis cerita fantasi siswa kelas VII $\mathrm{H}$ memberikan respons sangat positif.

Yang dilakukan oleh peneliti bersama guru pada akhir siklus II menunjukkan bahwa pelaksanaan pebelajaran kemampuan menulis cerita fantasi dengan penggunaan video anak "Pertualangan Alice di Negeri Ajaib" secara umum telah berjalan sesuai dengan rencana. Jadi, pembelajaran kemampuan menulis dengan penggunaan video anak "Pertualangan Alice di Negeri Ajaib" dapat meningkatkan kemampuan menulis cerita fantasi siswa kelas VII H SMP Negeri 2 Sawan. Hasil catatan lapangan dan tes menulis siswa menunjukkan bahwa indikator keberhasilan penelitian ini telah tercapai sehingga tindakan dihentikan.

Ada beberapa temuan penting yang dibahas pada bagian ini. Pertama, penggunaan video anak "Pertualangan Alice di Negeri Ajaib" dapat meningkatkan kemampuan siswa dalam pembelajaran menulis cerita fantasi. Kedua, respons siswa sangat positif dalam pembelajaran menulis cerita fantasi dengan penggunaan video anak "Petualangan Alice di Negeri Ajaib". Terhadap temuan tersebut dapat dijelaskan sebagai berikut.
Temuan pertama,
pembelajaran menulis cerita fantas
dengan penggunaan video anak
"Pertualangan Alice di Negeri Ajaib" terlihat pada pencapaian skor pada saat dilaksanakannya pratindakan, tindakan siklus I, dan tindakan siklus II bahwa setiap tindakan telah mengalami peningkatan. Nilai rata-rata klasikal pratindakan adalah 68,83 , nilai rata-rata klasikal pada tindakan siklus I adalah 77,58 , dan nilai rata-rata pada tindakan siklus II adalah 81,58. Jadi, dalam tindakan siklus II siswa $100 \%$ mengalami peningkatan sesuai dengan KKM yang sudah ditentukan yaitu 75. Peningkatan tersebut terjadi karena adanya pembaharuan di dalam proses pembelajaran yang membuat siswa lebih aktif belajar dan ditambah lagi dengan adanya media sebagai penunjang sehingga pembelajaran terkesan lebih menarik dan tidak membosankan.

Penggunaan video anak

"Pertualangan Alice di Negeri Ajaib" sangat tepat diterapkan dalam pembelajaran menulis cerita fantasi. Penggunaan video anak "Pertualangan Alice di Negeri Ajaib" dapat membantu meningkatkan daya imajinasi siswa dalam menulis cerita fantasi. Hal itu sesuai dengan pendapat Mahadewi dkk., (dalam Atambuasih, 2012) yang mengemukakan bahwa ada empat peranan media video dalam proses pembelajaran, yaitu (1) dapat menarik perhatian siswa sehingga menimbulkan motivasi belajar, (2) memperjelas makna bahan pengajaran sehingga mudah dipahami siswa, (3) metode pengajaran lebih bervariasi, dan (4) siswa lebih banyak melakukan kegiatan belajar.

Tidak semua media bisa dimanfaatkan begitu saja. Penggunaan media perlu disesuaikan dengan karakteristik materi, peralatan yang tersedia, termasuk juga kemampuan guru menggunakan media. Di samping itu, juga perlu diketahui peranan masing-masing media dan kecocokannya terhadap topik atau materi yang sedang dibahas.

Selain itu, media sangat penting dalam suatu proses pembelajaran. Hal ini 
sejalan dengan pendapat Hamijaya (dalam Ahmad Rohani, 1997) yang menyatakan bahwa media merupakan bentuk perantara yang dipakai orang untuk mengungkapkan idenya, sehingga ide atau gagasan itu sampai pada penerima. Dengan menggunakan video anak "Pertualangan Alice di Negeri Ajaib", siswa merasa dibantu dalam mengeluarkan ide atau gagasan saat menulis kerangka cerita fantasi melalui video anak "Petualangan Alice di Negeri Ajaib" yang ditonton.

Seperti yang diungkapkan oleh Hakim (2005), menulis merupakan upaya mengekspresikan apa yang dilihat, dialami, dirasakan, dan dipikirkan ke dalam bahasa tulis. Dengan adanya video "Pertualangan Alice di Negeri Ajaib" yang ditonton atau dilihat oleh siswa, siswa akan dengan mudah mengekspresikan apa yang telah dilihatnya.

Temuan penelitian di atas sejalan dengan Sujana (2012) yang juga menggunakan video klip dalam penelitiannya dapat meningkatkan hasil pembelajaran setelah melalui dua siklus pembelajaran. Hasil penelitian tersebut, dari 29 siswa $(70,73 \%)$ pada siklus I, menjadi 36 siswa $(87,80 \%)$ pada siklus II. Penelitian yang dilakukan I Made Sujana lebih menekankan pada penggunaan media video klip.

Selanjutnya, Ni Putu Ayu Nila Purmita Sari (2015) melakukan sebuah penelitian yang berjudul Penggunaan Pendekatan Saintifik Bermedia Video Anak "Si Bolang" untuk Meningkatkan Kemampuan Menulis Cerpen Pada Siswa Kelas VII 15 SMP Negeri 2 Singaraja. Hasil penelitian ini adalah peningkatan menulis cerpen melalui video anak "Si Bolang". Hasil penelitian tersebut, dari 21 siswa $(58,33 \%)$ pada siklus I, menjadi 34 siswa $(94,44 \%)$ pada siklus II. Penelitian yang dilakukan oleh Ni Putu Ayu Purmita Sari lebih menekankan pada penggunaan pendekatan saintifik bermedia video anak.

Selain itu, Made Rospita Pradnya Dewi (2017) melakukan sebuah penelitian yang berjudul Penggunaan Media Audio Visual dalam Pembelajaran Menulis Teks Pidato di Kelas X IPA 8 SMA Negeri 1
Kuta Utara. Hasil penelitian ini adalah adanya peningkatan dalam menulis teks pidato dengan menggunakan media audio visual. Penelitian yang dilakukan oleh Made Rospita Pradnya Dewi lebih menekankan pada penggunaan media audio visual.

Temuan kedua, yaitu siswa memberikan respons sangat positif terhadap penggunaan video anak "Pertualangan Alice di Negeri Ajaib" untuk meningkatkan kemampuan menulis cerita fantasi. Siswa menjadi sangat senang dan aktif mengikuti pembelajaran menulis cerita fantasi melalui penggunaan video anak "Pertualangan Alice di Negeri Ajaib". Rasa senang dan aktif tersebut dapat dilihat dari rata-rata respons siswa yang positif. Hasil belajar adalah kemampuan yang dimiliki siswa setelah ia menerima pengalaman belajarnya (Sudjana, 2009). Hasil tersebut dapat dilihat pada siklus I skor rata-rata respons siswa adalah 41,51 (positif), kemudian skor rata-rata respons siswa meningkat menjadi 46,77 (sangat positif) pada siklus II. Skor itu menunjukkan bahwa telah terjadi peningkatan respons siswa.

Terkait dengan respons siswa, diperoleh hasil bahwa respons siswa kelas VII $\mathrm{H}$ SMP $\mathrm{N} 2$ Sawan dalam pembelajaran menulis cerita fantasi dengan penggunaan video anak "Petualangan Alice di Negeri Ajaib" sangat positif. Sesuai dengan hasil kuesioner/angket, rata-rata respons siswa terhadap penggunaan video anak "Pertualangan Alice di Negeri Ajaib" dikatakan positif. Hal ini disebabkan adanya situasi yang memungkinkan terjadinya kegiatan pembelajaran optimal, media pembelajaran tidak monoton serta pemilihan materi yang otentik.

Siswa tidak ada lagi yang terlihat bosan dalam proses pembelajaran menulis cerita fantasi. Siswa yang awalnya kurang bersemangat dalam pembelajaran, kini sudah bersemangat. Hal ini dikarenakan guru menggunakan penunjang dalam kegiatan belajar yaitu dengan menggunakan media audio-visual. Media ini mempunyai kemampuan yang lebih baik, karena meliputi kedua jenis 
media auditif (mendengar) dan visual (melihat) sehingga siswa tidak bosan dalam belajar dan mempunyai banyak ide dalam memproduksi tulisan yang baik. Dengan ditunjang menggunakan media, siswa sangat antusias mengikuti pembelajaran. Hal ini sejalan dengan pernyataan Sadiman (2005) bahwa media merupakan segala sesuatu yang dapat digunakan untuk menyalurkan pesan dari pengirim ke penerima sehingga dapat merangsang pikiran, perasaan, minat serta perhatian siswa sedemikian rupa dalam proses belajar terjadi. Pemilihan media sebagai alat bantu yang tepat akan mampu menimbulkan semangat belajar siswa, meningkatkan hasil belajar siswa, dan mencegah kebosanan siswa untuk belajar. Pentingnya pemilihan media yang tepat pada suatu pembelajaran, dikarenakan pula oleh fungsi media pembelajaran sendiri, yakni untuk meningkatkan hasil belajar siswa.

Penelitian sejenis yang dijadikan referensi dalam penelitian ini adalah penelitian Ni Putu Ayu Purmita Sari (2015) yang berjudul Penggunaan Pendekatan Saintifik Bermedia Video Anak "Si Bolang" untuk Meningkatkan Kemampuan Menulis Cerpen Pada Siswa Kelas VII SMP Negeri 2 Singaraja. Hasil penelitian ini memeroleh hasil yang sama dalam respons siswa, yakni pada siklus I adanya respons positif $(44,36)$ menjadi sangat positif $(46,27)$ pada siklus II. Skor itu menunjukkan bahwa telah terjadi peningkatan respons siswa, setelah siswa mengalami proses pembelajaran dengan media pembelajaran yang diterapkan guru.

Penelitian ini hanya dibatasi dengan penggunaan video anak pada kemampuan menulis saja. Penggunaan video anak "Petualangan Alice di Negeri Ajaib" juga bisa diterapkan pada pembelajaran membaca, berbicara, dan menyimak. Kita tahu bahwa berbicara, membaca, dan menyimak merupakan catur tunggal yang tak bisa dipisahkan dan sangat berkaitan satu sama lain. Hal itu sejalan dengan apa yang dikatakan oleh Tarigan (1994) setiap keterampilan berbahasa itu erat sekali berhubungan dengan ketiga keterampilan lainnya dengan cara yang beraneka ragam. Keempat keterampilan itu pada dasarnya merupakan satu kesatuan atau caturtunggal. Itu berarti, penggunaan video anak ini bisa digunakan untuk keterampilan yang lain dan ini merupakan peluang bagi peneliti lain untuk dijadikan sebagai bahan penelitian.

\section{SIMPULAN DAN SARAN}

Ada beberapa hal yang menjadi simpulan dalam penelitian ini. Pertama, langkah-langkah pembelajaran dengan penggunaan video anak "Pertualangan Alice di Negeri Ajaib" yang diterapkan oleh guru berdasarkan standar kompetensi dasar, telah dilaksanakan sesuai prosedur yang dirancang/ dibuat. Media berupa video yang digunakan adalah video anak "Pertualangan Alice di Negeri Ajaib". Pada pertemuan tindakan siklus I, kegiatan pembelajaran berjalan dengan baik. Namun, dari 14 aspek pembelajaran, hanya 11 aspek yang dilaksanakan sedangkan 3 aspek lagi tidak dapat dilaksanakan. Pada tindakan siklus II, 14 aspek pembelajaran dapat dilaksanakan dengan baik sesuai prosedur.

Kedua, penggunaan video anak "Pertualangan Alice di Negeri Ajaib" dapat meningkatkan kemampuan menulis cerita siswa kelas VII H SMP Negeri 2 Sawan. $\mathrm{Hal}$ itu dapat dilihat dari peningkatan skor rata-rata yang diperoleh oleh siswa. Skor rata-rata yang diperoleh oleh siswa pada nilai awal sebelum tindakan yang dilakukan adalah 68,83 yang berkategori cukup, siklus I adalah 77,58 yang berkategori baik, sedangkan skor rata-rata yang diperoleh siswa setelah tindakan pada siklus II adalah 81,58 yang berkategori baik. Hal itu membuktikan bahwa rata-rata skor siswa pada siklus I mengalami peningkatan pada siklus II. Ketuntasan klasikal presentase hasil menulis cerita fantasi siswa pada siklus I mencapai $77,41 \%$ dan pada siklus II telah mencapai $96,77 \%$ bahkan melebihi kriteria yang telah ditentukan, yakni $75 \%$ siswa memeroleh nilai di atas 75 . 
Ketiga, respons siswa dalam pembelajaran menulis cerita fantasi dengan penggunaan video anak "Pertualangan Alice di Negeri Ajaib" tergolong sangat baik. Pada siklus I, ratarata respons siswa mencapai 41 dengan kategori baik. Pada siklus II meningkat dengan rata-rata 46 atau meningkat 5 poin dengan kategori sangat baik.

Berdasarkan temuan-temuan dalam penelitian ini, peneliti menyampaikan beberapa saran. (1) Penggunaan video anak "Pertualangan Alice di Negeri Ajaib" sangatlah efektif digunakan dalam pembelajaran menulis cerita fantasi. Guru pada sekolah penelitian ini maupun di luar tempat penelitian ini hendaknya bisa menggunakan media video anak "Pertualangan Alice di Negeri Ajaib" sebagai salah satu upaya untuk meningkatkan hasil kemampuan menulis cerita fantasi siswa. (2) Hasil yang dicapai dalam penelitian ini diharapkan bisa dimanfaatkan dan dijadikan pijakan oleh peneliti lain untuk meneliti sisi-sisi yang berbeda mengenai penggunaan video anak "Pertualangan Alice di Negeri Ajaib" untuk meningkatkan kemampuan menulis cerita fantasi siswa.

\section{DAFTAR PUSTAKA}

Dewi, Made Rospita Pradnya. 2017. Penggunaan Media Audio Visual dalam Pembelajaran Menulis Teks Pidato di Kelas X IPA 8 SMA Negeri 1 Kuta Utara. Skripsi (tidak diterbitkan). Singaraja: Universitas Pendidikan Ganesha.

Djamarah, Bahri dan Aswan Zain. 1995. Strategi Belajar Mengajar. Jakarta: PT. Asdi Mahasatya.
Effendy, Heru. 2006. Mari Membuat Film, Panduan Untuk Menjadi Produser. Yogyakarta: Sinar Baru.

Hakim, Arief. 2005. Kiat Menulis Artikel di Media: dari pemula sampai mahir. Bandung: Nuasa Cendikia.

Kartono. 2009. Menulis Tanpa Rasa Takut Membaca Realitas dengan Kritis. Yogyakarta: Kanisius.

Rohani, Ahmad. 1997. Media Instruksional Eduktif. Jakarta: Rineka Cipta.

Sadiman, Arief S, dkk. 2005. Media Pendidikan: Pengertian,

Pengembangan, dan Pemanfaatannya. Jakarta: PT Raja Grafindo Persada.

Sari, Ni Putu Ayu Nila Purmita. 2015. Penggunaan Pendekatan Saintifik Bermedia Video Anak "Si Bolang" untuk Meningkatkan Kemampuan Menulis Cerpen Pada Siswa Kelas VII 15 SMP Negeri 2 Singaraja. Skripsi (tidak diterbitkan). Singaraja: Universitas Pendidikan Ganesha.

Semi, Atar. 1990. Menulis Efektif. Padang: Angkasa Raya.

Sudjana, N. 2009. Penilaian Hasil Belajar Mengajar. Bandung: PT. Remaja Rosdakarya.

Sujana, I Made. 2012. Peningkatan Kemampuan Menulis Cerpen Menggunakan Media Video Klip Siswa Kelas VII 1 SMP Negeri 1 Tampaksiring. Skripsi (tidak diterbitkan). Singaraja: Universitas Pendidikan Ganesha.

Tarigan, Henry Guntur. 1994. Menulis sebagai suatu Keterampilan Berbahasa. Bandung: Angkasa. 